\title{
CHARACTERIZATION OF Aeromonas SPECIES ISOLATED FROM AN ESTUARINE ENVIRONMENT
}

\section{Norma Suely Evangelista-Barreto ${ }^{1,2^{*}}$; Fatima Cristiane Teles de Carvalho ${ }^{1}$, Regine Helena S. dos Fernandes Vieira ${ }^{1}$; Cristhiane Moura Falavina dos Reis³; Andrew Macrae'; Dália dos Prazeres Rodrigues ${ }^{3}$}

\author{
${ }^{1}$ Instituto de Ciências do Mar- LABOMAR, Universidade Federal do Ceará, Fortaleza, CE, Brasil; ${ }^{2}$ Universidade Federal do \\ Recôncavo da Bahia, Cruz das Almas, BA, Brasil; ${ }^{3}$ Laboratório de Enterobactérias, Instituto Oswaldo Cruz, Fundação Oswaldo \\ Cruz, Rio de janeiro, RJ, Brasil; ${ }^{4}$ Instituto de Microbiologia Professor Paulo de Góes, Universidade Federal do Rio de Janeiro, Rio \\ de Janeiro, RJ, Brasil.
}

Submitted: June 20, 2009; Approved: October 06, 2009.

\begin{abstract}
Thirty water samples were collected, at two week intervals, from the estuary of the River Cocó. The aim was to characterize the presence, distribution and types of Aeromonas spp, in the estuary of the River

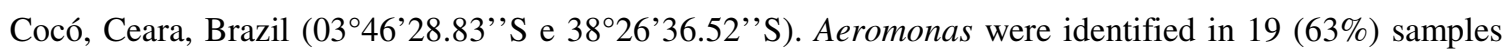
analyzed by plating and CFU counts. Presence/absence tests were positive for 11 (37\%) of the samples resulting in the detection of Aeromonas in a total of $23(77 \%)$ of samples. CFU counts varied from $<10$ to $1.4 \times 10^{4} \mathrm{CFU} \mathrm{mL}{ }^{-1}$. From the isolated strains seven species of Aeromonas were identified: A. caviae (29/69), A. veronii bv. sobria (13/69), A. veronii bv. veronii (8/69), A. trota (6/69), A. media (5/69), A. sobria (4/69) and A. hydrophila and Aeromonas sp. (2/69). Of the 38 strains tested, 23 (60\%) showed resistance to at least one of the eight antimicrobials. Multiple resistance to antibiotics was observed in $A$. caviae, A. media, A. sóbria and A. veronii bv. sobria. Aeromonas caviae showed the highest multiple resistance, being resistant to four antibiotics. The presence of those microorganisms may contribute to the occurrence of gastroenteritis, mainly in children, since they are considered opportunists.
\end{abstract}

Key words: Aeromonas, Estuary, Antibiotics

\section{INTRODUCTION}

Aquatic environments are used worldwide for water supply, energy production, irrigation, navigation, aquaculture, and primary and secondary contact activities. Nevertheless, in the last decades these environments have been threatened by human misuse with detrimental consequences for mankind as a whole (25). Today, many countries are suffering from serious environmental impacts caused for example by domestic and industrial sewage discharged into rivers (37). Therefore, environmental pollution has become a public issue around the world.

According to the IBGE census (2000), the city of Fortaleza has an annual population growth of $2.8 \%$ due to immigration from rural areas or from other Brazilian states. These immigrants contribute to the settlements in river shore

*Corresponding Author. Mailing address: Campus Universidade Cruz das Almas, S/N. CCAAB/NEPA, Cx Postal 69. CEP: 44380-000, Cruz das Almas, BA, Brasil.; Tel.: +00-55-75-3621-1558.; E-mail: nsevangelista@yahoo.com.br 
areas, thus increasing waterborne disease outbreaks (5). The River Cocó, like most of Brazilian rivers, has been affected by human activities which altered its characteristics and development. Hence, it is important to develop water quality monitoring programs in the affected areas to collect information which may help institutions make the right decisions.

Members of the genus Aeromonas currently belong to the family Aeromonadaceae, and are characterized as short, Gram negative, oxidase-positive, rod-shaped bacteria, which metabolise glucose by both the respiratory and fermentative pathways and show resistance to the vibriostatic agent $\mathrm{O} / 129$. It can be divided into two groups: the first includes the psychotrophic Aeromonas, represented by Aeromonas salmonicida and the second, by the mesophyllic Aeromonas (9).

In Brazil, several studies appoint the occurrence of these pathogens isolated from aquatic ecosystem, food origin (fish, oysters, mussels and crabs) and coetaneous lesions in humans caused by fisheries $(8,31)$. These studies are important to Public Health due to the association of some of these microorganisms on foodborne disease and extraintestinal infections $(14,30)$. Previous studies have demonstrated that the genus Aeromonas is the second cause of gastroenteritis in children and the fifth in adult patients (15).

The genus Aeromonas is composed of a large number of different taxa. Currently this group is included in the family Aeromonadaceae, at least 17 genome-species are recognized in the genus (23). However, Aeromonas hydrophila, A. veronii, A. caviae, A. jandaei and $A$. schubertii are recognized as human and animal (fish) pathogens (16). Despite the high incidence of infections of Aeromonas combined with other pathogens isolated from patients with diarrhea, the virulence factors that cause gastroenteritis are still not totally defined (1). Among the species above A. hydrophila has attracted attention due to its frequent association with infections in humans (22). Infections are principally found in patients with a history of accidents, where there has been exposure of wounds to aquatic environments, in immunodeficient individuals and commonly are associated with meningitis, endocarditis, peritonitis, hemolytic uremic syndrome or septicemia (24).

The increasing bacterial resistance to antibiotics has become a public health problem due to the fact that bacteria can be found in different niches. Among those niches, the aquatic environment is considered the most efficient for the selection of resistant populations, as well as for the exchange of resistance genes by means of mobile genetic elements (38), such as plasmids and transposons (33) which encode resistance to antibiotics. Evangelista-Barreto (8) analysed isolated oysters from the Coco River and observed antibiotic resistance in $48 \%$ of the aeromonas studied.

The Food and Agriculture Organization/World Organization Health (FAO/WOH) commission recommends that to prevent waterborne disease in developing countries, aquatic environments directly impacting human populations should be characterized physically, chemically and microbiologically. In light of this recommendation, the present study aimed to quantify and identify Aeromonas spp in water samples collected from the Cocó River estuary in the Sabiaguaba region (Fortaleza, Ceará, Brazil), and to verify the isolated strains susceptibility to antibiotics.

\section{MATERIALS AND METHODS}

\section{Sample collection}

Thirty water samples were collected on a weekly basis from april to october from one point in the Cocó river estuary (Brazil), located $0.2 \mathrm{Km}$ from the river's mouth $\left(03^{\circ} 46^{\prime} 28.83^{\prime \prime} \mathrm{S}\right.$ and $\left.38^{\circ} 26^{\prime} 36.52^{\prime}{ }^{\prime} \mathrm{W}\right)$.

Water samples were collected at margins and in the middle of the river, about $30 \mathrm{~cm}$ depth in $1000 \mathrm{~mL}$ sterilized bottles. Samples were transported in refrigerated isothermal boxes to the microbiology laboratory at the Instituto de Ciências do Mar/LABOMAR/UFC and analyzed immediately. Physicochemical parameters such as $\mathrm{pH}$, salinity and water temperature were determined using standard methods (2). 


\section{Bacterial Isolation}

The strains were isolated by the direct plating (DP) and the presence/absence methods (P/A) on Pseudomonas Aeromonas selective agar (GSP, Merck), with $20 \mu \mathrm{g} \mathrm{mL} \mathrm{m}^{-1}$ of ampicillin (GSPA) added.

For Aeromonas enumeration the DP method was used by spreading $0.1 \mathrm{~mL}$ of each dilution $\left(10^{-1}-10^{-3}\right)$ onto the surface of two GSPA agar plates and incubating at $28^{\circ} \mathrm{C}$ for $24 \mathrm{~h}$. After $24 \mathrm{~h}$ presumptive colonies (yellow colonies of $2-3 \mathrm{~mm}$, surrounded by a yellow-zone) were counted. For Aeromonas P/A test the trypticase soy broth (TSB, Difco) added with 20 $\mu \mathrm{g} \mathrm{mL}^{-1}$ of ampicillin (TSBA) was used. Aliquots of $10 \mathrm{~mL}$ from the initial dilution $\left(10^{-1}\right)$ were inoculated, in duplicate, in $10 \mathrm{~mL}$ of TSBA and incubated at $28^{\circ} \mathrm{C}$ for $24 \mathrm{~h}$. After incubation, portions from each tube were streaked onto the surface of two GSPA agar plates and re-incubated. The P/A test was carried out in duplicate.

Aeromonas isolates were counted using a Phoenix mod. EC 550A counter from plates with between 25-250 colonies. Aeromonas spp were initially identified based on being amylase positive, yellow in colour and showing a clear halo around each colony.

\section{Bacterial identification}

From each plate typical colonies (2 to 5 ) were transferred to trypticase soy agar (Difco) for biochemical identification tests according to Palumbo et al. (28). The positive control was Aeromonas ATCC 7966.

\section{Antimicrobial susceptibility test}

The antimicrobial susceptibilities of Aeromonas isolates were tested in vitro according to standard procedures CLSI (4) with the following antibiotics: ceftriaxone $30 \mu \mathrm{g}$; cephalothin $30 \mu \mathrm{g}$; chloramphenicol 30 $\mathrm{g}$; ciprofloxacin $5 \mu \mathrm{g}$; nalidixic acid $30 \mu \mathrm{g}$; nitrofurantoin $300 \mu \mathrm{g}$; sulfamethoxazole-trimethoprim $23.75 / 1.25 \mu \mathrm{g}$ and tetracycline $30 \mu \mathrm{g}$.

\section{RESULTS AND DISCUSSION}

Of the 30 water samples, $23(77 \%)$ contained culturable
Aeromonas spp; this observation is similar to Dumonter et al. (6) who found Aeromonas spp in $62 \%$ of water samples and marine sediments from along $900 \mathrm{~km}$ of the Italian coast. Fuzihara et al. (9) analysed treated and untreated water samples collected in the interior of São Paulo, and reported the presence of aeromonas in $6.3 \%$ and $55.3 \%$ of the samples, respectively.

CFU counts for Aeromonas spp varied from $<10$ to $1.4 \mathrm{x}$ $10^{4} \mathrm{CFU} \mathrm{mL}^{-1}$ (Table 1). We note that a CFU's of $10 \mathrm{~mL}^{-1}$ is very low and is likely to reflect experimental technique for a non enriched medium using $0.1 \mathrm{~mL}$ sample is very close to the minimal detection limits for Aeromonas spp from this environment. TSBA broth enriches for Aeromonas spp and was used in the presence absence tests combined with $10 \mathrm{~mL}$ samples, given that samples were enriched, they were not counted. Maalej et al. (21) studying the seasonal dynamics of Aeromonas in treated urban effluent and in surface marine waters along the coast of Sfax (Mediterranean Sea, Tunisia), found counts varying from $1.48 \times 10^{5}$ to $2.2 \times 10^{8} \mathrm{CFU} 100$ $\mathrm{mL}^{-1}$ for the effluent and $7.9 \times 10^{3} \mathrm{CFU} 100 \mathrm{~mL}^{-1}$ for the marine waters.

While there is no specific legislation which stipulates limits concerning the numbers of these microorganisms, we must not forget that their presence in this area of the estuary is of social importance. These waters are used for leisure activities and they are also used for oyster fishing, which is normally eaten raw. Generally, Aeromonas spp are the most commonly found contaminants in fish and marine products, which to an extent is explained by their ubiquitous nature in aquatic environments Hãnninen et al. (10). In rivers, they form part of the normal microbiota being able to multiply under normal environmental conditions.

The microbiological properties of waterways are altered depending on source, type and quantity of pollutant entering them. That noted, the presence of Aeromonas spp can not always be directly related to fecal pollution Dumonter et al. (6). In this study, it is important to highlight that upstream of the water sample site the river flows through several shantytowns without any basic sanitation system, thus increasing environmental contamination. 
Table 1. Quantification of Aeromonas species from the Cocó River estuary (Fortaleza, Brazil) by presence/absence (P/A) and direct plating $\left(\mathrm{CFU} \mathrm{mL} \mathrm{mL}^{-1}\right)$ methods

\begin{tabular}{|c|c|c|c|c|}
\hline Collect & $\mathbf{P} / \mathbf{A}$ & $*$ Species $\left(n^{\circ}\right.$ of strains) & CFU/mL & $*$ Species ( ${ }^{\circ}$ of strains) \\
\hline $1^{\mathrm{o}}$ & $\mathrm{A}$ & - & $1.4 \times 10^{4}$ & As, Avs \\
\hline $2^{o}$ & A & - & $1.2 \times 10^{4}$ & Avs, Ac \\
\hline $3^{\circ}$ & A & - & $1.7 \times 10^{3}$ & Ac \\
\hline $4^{\circ}$ & $\mathrm{P}$ & Avs, Ac & $<10$ & Ah, Avs \\
\hline $5^{\circ}$ & A & - & $<10$ & - \\
\hline $6^{\circ}$ & $\mathrm{P}$ & Avv & $3.2 \times 10^{3}$ & Avs \\
\hline $7^{\circ}$ & A & - & $2.9 \times 10^{3}$ & As \\
\hline $8^{\circ}$ & A & - & $<10$ & - \\
\hline $9^{\circ}$ & $\mathrm{P}$ & Ac, Avs & $1,0 \times 10^{3}$ & Ac \\
\hline $10^{\circ}$ & A & - & $5.0 \times 10^{2}$ & Avs \\
\hline $11^{\circ}$ & A & - & $2.1 \times 10^{3}$ & Ac \\
\hline $12^{\circ}$ & A & - & $3.3 \times 10^{2}$ & Am, Ac \\
\hline $13^{\circ}$ & $\mathrm{P}$ & Ac, At & $3.5 \times 10^{2}$ & Ac, Avs \\
\hline $14^{\circ}$ & $\mathrm{P}$ & Asp, At, Ac & $<10$ & - \\
\hline $15^{\circ}$ & A & - & $1,6 \times 10^{2}$ & Avv \\
\hline $16^{\circ}$ & A & - & $3.0 \times 10^{2}$ & Ac, At \\
\hline $17^{\circ}$ & $\mathrm{P}$ & $\mathrm{Ac}$ & $1.7 \times 10^{2}$ & Avv, Ac \\
\hline $18^{\circ}$ & $\mathrm{P}$ & Ac, At & $<10$ & - \\
\hline $19^{\circ}$ & A & - & $2.1 \times 10^{3}$ & $\mathrm{Ac}$ \\
\hline $20^{\circ}$ & $\mathrm{P}$ & Avv & $<10$ & - \\
\hline $21^{\circ}$ & A & - & $<10$ & - \\
\hline $22^{\circ}$ & $\mathrm{P}$ & $\mathrm{Ah}$ & $<10$ & - \\
\hline $23^{\circ}$ & $\mathrm{P}$ & Avs & $<10$ & Asp \\
\hline $24^{\circ}$ & A & - & $<10$ & - \\
\hline $25^{\circ}$ & A & - & $<10$ & - \\
\hline $26^{\circ}$ & A & - & $9.9 \times 10^{2}$ & Ac, Avs \\
\hline $27^{\circ}$ & A & - & $<10$ & Am \\
\hline $28^{\circ}$ & $\mathrm{A}$ & - & $<10$ & - \\
\hline $29^{\circ}$ & $\mathrm{P}$ & Ac & $<10$ & Am \\
\hline $30^{\circ}$ & A & - & $<10$ & - \\
\hline
\end{tabular}

Table 1 identifies and quantifies the isolates obtained by direct plating and presence absence tests from the water samples. With the direct plating method, 19 (63\%) samples tested positive for Aeromonas spp, while the P/A method 11 (37\%) samples were positive for Aeromonas isolates. Combining the results resulted in detection of Aeromonas in 23 samples $(77 \%)$.

TSBA was chosen as an enrichment medium because authors including Hãnninen et al. (12) found it to be excellent for detecting the presence of Aeromonas. Nevertheless, direct counting of CFU's of Aeromonas spp proved more successful in detecting this genus. Seven species of Aeromonas were identified from the samples analysed, the most common being
A. caviae detected in 14 samples (47\%), A. veronii biovar sobria in 09 (30\%), A. veronii bv. veronii and A. trota in 04 (13\%), A. media in 03 (10\%) and A. hydrophila, A. sobria e Aeromonas sp. in $02(07 \%)$ (Table 1). Although it is known that $A$. caviae predominates in marine waters, it can also be found in water contaminated by sewage (34). The indigenous nature of Aeromonas spp in aquatic environments highlights that these organisms can play an important role as opportunistic pathogens (20). Chopra \& Houston (3) reported that the species, A. hydrophila, A. veronii bv. sobria and A. caviae are commonly isolated from human infections and demonstrated their capacity to produce a variety of biologically active extra-cellular products. 
Among the 69 strains isolated using both isolation methods, the following were identified A. caviae in 29 (42\%), A. veronii bv. sobria in 13 (19\%), A. veronii bv. veronii in 08 (11\%), A. trota in $06(07 \%)$, A. media in $05(07 \%)$, A. sobria in $04(06 \%)$ Aeromonas spp and A. hydrophila in 02 (03\%) (Table 2). The species A. caviae as well as A. hydrophila and A. sobria are capable of causing diarrhea; especially if contaminated water is ingested by susceptible individuals (28).
Aeromonas hydrophila and A. sobria have been described as the most virulent phenospecies among the mesophile Aeromonas (13). In Brazil, an acute diarrhea outbreak, with 2170 cases, occurred between January and July, 2004, in São Bento do Una, Pernambuco. In this case, Aeromonas species were the most frequent (19.5\%) and the main isolates were $A$. caviae $(9.8 \%)$, A. veronii biovar sobria $(3.9 \%)$ and A. veronii biovar veronii (2.6\%) (14).

Table 2. Percentage of Aeromonas isolated from the Cocó River estuary (Fortaleza, Brazil), by presence/absence (P/A) and direct plating $\left(\mathrm{CFU} \mathrm{mL} \mathrm{mL}^{-1}\right)$ methods.

\begin{tabular}{lccc}
\hline Species & P/A (\%) & ${\text { CFU } \mathbf{~ m L}^{-\mathbf{1}}(\boldsymbol{\%})}$ & Total identified strains $(\%)$ \\
\hline A. caviae & $12(46)$ & $17(40)$ & $29(42)$ \\
A. hydrophila & $01(04)$ & $01(02)$ & $02(03)$ \\
A. media & no detected & $05(12)$ & $05(07)$ \\
A. sobria & no detected & $04(09)$ & $04(06)$ \\
A. trota & $05(19)$ & $01(02)$ & $06(09)$ \\
A. veronii bv. sobria & $03(12)$ & $10(23)$ & $13(19)$ \\
A. veronii bv. veronii & $04(15)$ & $04(09)$ & $08(11)$ \\
Aeromonas sp. & $01(04)$ & $01(02)$ & $02(03)$ \\
Total & $26(100)$ & $43(100)$ & $69(100)$ \\
\hline
\end{tabular}

Table 3 shows the results of resistance to eight antimicrobial agents for the 38 strains of Aeromonas spp tested. Of the 38 strains tested $23(60 \%)$ showed resistance to at least one of the antimicrobials. Antimicrobial resistance is a fact which is increasingly worrying health authorities, due to its increasing occurrence each year (29). According to the literature, the majority of Aeromonas are susceptible to tetracycline, aminoglycosides, third generation cephalosporins and the quinolones (16), although studies have shown high resistance to tetracycline (17), and combined oxytetracycline (OTC) and sulphadiazine/trimethoprim (36).

Aeromonas strains were shown to be less sensitive to trimethoprim-sulfamethoxazole, with $21(55 \%)$ of the strains showing resistance to this antimicrobial. Aeromonas caviae was the species which presented the highest resistance $(29 \%)$, followed by A. media (08\%), A. veronii both biogroups (05\%) and $A$. media and A. trota with $03 \%$.

In this study, all A. trota, A. hydrophila, A. sobria and A. veronii bv. veronii strains were shown to be sensitive to this antibiotic. A. caviae, A. veronii bv. sobria and A. media strains were sensitive to tetracycline in 92,90 and $33 \%$ of tests respectively. Similar results were found by Rall et al. (32) who observed sensitivity to this antimicrobial from $100 \%$ of $A$. sobria strains and $93 \%$ of $A$. caviae strains. Limited/rate resistance to tetracycline from strains of Aeromonas spp is hypothesised as being related to acquired resistance through mobile genetic elements/plasmids (13).

Nalidixic acid is an antimicrobial which can be applied with great success in the treatment of "traveller's diarrhoea" caused by these microorganisms (7). In this study, only $13 \%$ of 
the strains showed resistance to this antimicrobial. The resistance to quinolones and nalidixic acid is considered to be chromosomally mediated, as a result of drug resistant isolates selective pressure (11), or even multiplication of resistant clones (18). The relation between the increasing number of aquatic bacteria resistant to antibiotics and their hability to uptake and transfer resistance genes, is a well known fact (33).

Multiple resistance was observed in A. cavaie, A. media, A. sobria e A. veronii bv. sobria. The strains of $A$. caviae were multi-resistant to four $(50 \%)$ of the antimicrobials tested, followed by $A$. sobria and $A$. veronii bv. sobria, which were resistant to three (37\%), A. media, which was resistant to two (25\%), and A. hydrophila, A. trota and A. veronii bv. veronii, which were each resistant to one (12\%). The isolation of multiresistant aquatic Aeromonas species (including trimethoprimsulphamethoxazole and nalidixic acid) from freshwater in other parts of the world (10) along with our own findings warrant the need to take proper measures to prevent the introduction of resistant aeromonas into water sources used by humans, because the ingestion of contaminated fish may result in resistance gene transfer from fish to the human intestinal microbiota.

Table 3. Antibiotics susceptibility of Aeromonas spp strains isolated from from estuary of the Cocó river (Fortaleza, Brazil).

\begin{tabular}{lrrrrrrrr}
\hline \multicolumn{1}{c}{$\begin{array}{c}\text { Antibiotics* } \\
\text { Species }\end{array}$} & TE & F & AK & CIP & CRO & SXT & C & NA \\
\multicolumn{1}{c}{ S } & & & & & & & \\
\hline A. caviae $(\mathrm{n}=13)$ & $12(92)$ & $13(100)$ & $12(92)$ & $13(100)$ & $13(100)$ & $02(15)$ & $13(100)$ & $11(85)$ \\
A. media $(\mathrm{n}=03)$ & $01(33)$ & $03(100)$ & $03(100)$ & $03(100)$ & $03(100)$ & $0,0(0)$ & $03(100)$ & $03(100)$ \\
A. sobria $(\mathrm{n}=2)$ & $02(100)$ & $02(100)$ & $01(50)$ & $02(100)$ & $02(100)$ & $01(50)$ & $02(100)$ & $01(50)$ \\
A. hydrophila $(\mathrm{n}=2)$ & $02(100)$ & $02(100)$ & $02(100)$ & $02(100)$ & $02(100)$ & $02(100)$ & $02(100)$ & $01(50)$ \\
A. trota $(\mathrm{n}=4)$ & $04(100)$ & $04(100)$ & $04(100)$ & $04(100)$ & $04(100)$ & $03(75)$ & $04(100)$ & $04(100)$ \\
A. veronii bv. sóbria $(\mathrm{n}=10)$ & $09(90)$ & $10(100)$ & $10(100)$ & $10(100)$ & $10(100)$ & $08(80)$ & $10(100)$ & $09(90)$ \\
A. veronii bv. veronii $(\mathrm{n}=4)$ & $04(100)$ & $04(100)$ & $04(100)$ & $04(100)$ & $04(100)$ & $02(50)$ & $04(100)$ & $04(100)$ \\
Total $(\mathrm{n}=38)$ & $34(89)$ & $38(100)$ & $36(95)$ & $38(10)$ & $38(100)$ & $18(47)$ & $38(100)$ & $33(87)$ \\
\hline
\end{tabular}

*Tetracycline (TE), nitrofurantoin (F), cephalothin (KF), ciprofloxacin (CIP), ceftriaxone (CRO), sulfamethoxazole-trimethoprim (STX), chloramphenicol (C) and nalidixic acid (NA)

$\mathrm{n}=$ number of strains tested

Physical-chemical parameters of the water, including temperature, $\mathrm{pH}$ and salinity were recorded. Temperature varied from $28^{\circ}$ to $32^{\circ} \mathrm{C}$ (Table 3 ). In the seven collections where bacteria were not recovered, the temperature was found to be in the $30^{\circ}$ to $32^{\circ} \mathrm{C}$ range. Sautour et al. (35) observed that a temperature of $30^{\circ} \mathrm{C}$ and $\mathrm{pH} 7.0$ are ideal environmental parameters for the growth of A. hydrophila. The occurrence of blank results of the water samples may have been related to the fact that they were collected from water to a depth of $30 \mathrm{~cm} / \mathrm{sea}$ surface during the hottest part of the day $(12: 00 \mathrm{~h})$. The water sampling did not follow the tide regime, and sometimes took place in the presence of strong sunlight which may have raised water temperatures.

The $\mathrm{pH}$ of the water varied from 6.4 to 8.0 (Table 4), a range considered ideal by Khadori \& Fainstein (17) provided that the temperature is $28^{\circ} \mathrm{C}$. During the period of the study the water temperature was only above the $30^{\circ} \mathrm{C}$ range in $06(20 \%)$ samples of which $02(07 \%)$ samples of the samples did not yield bacteria (Table 4). One highly significant factor in understanding infections is knowledge of an organism's ecological niche, as this has an influence on the thermal scale of its growth and its ability to proliferate at the temperature of 
the host body. Aeromonas spp can produce enterotoxins at different temperatures (19).

The values for salinity varied from not detected to $3.6 \%$ (Table 4). This fact justifies the high percentage of positive samples obtained in the current study; as Palumbo et al. (27) demonstrated that Aeromonas spp grow in a maximum concentration of $4.5 \%$ sodium chloride $(\mathrm{NaCl})$. However there was a decrease in the scores of these microorganisms, mainly from the $18^{\text {th }}$ collection, coinciding with the dry season when an increase in salinity and temperature could be noted. Knochel (19) observing the growth of 80 strains of Aeromonas spp in different concentrations of salt, noted that at a temperature of

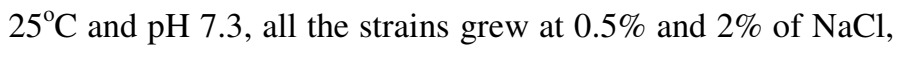
with only a few of them growing in the medium containing 4 and $6 \%$ of $\mathrm{NaCl}$.

The potential risk from Aeromonas spp to human health from aquatic environments has been stressed by several researchers, principally in infections caused by these microorganisms when related to recreation and other activities in aquatic environments. In the face of the results obtained, the presence of A. hydrophila, A. caviae, A. veronii and A. veronii bv. is highlighted as it is known that these species are involved in diverse outbreaks of gastroenteritis.

Table 4. Physical-chemical (temperature, $\mathrm{pH}$ e salinity) parameters determined from 30 water samples in the estuary of the Cocó river, Brazil.

\begin{tabular}{|c|c|c|c|c|c|c|c|}
\hline Samples & Temperature $\left({ }^{\circ} \mathrm{C}\right)$ & pH & Salinity (\%o) & Samples & Temperature $\left({ }^{\circ} \mathrm{C}\right)$ & pH & Salinity (\%o) \\
\hline $1^{\mathrm{a}}$ & 32 & 6.7 & no detected & $16^{\mathrm{a}}$ & 28 & 6.9 & 32 \\
\hline $2^{\mathrm{a}}$ & 29 & 7.4 & 1.0 & $17^{\mathrm{a}}$ & 30 & 7.6 & 17 \\
\hline $3^{\mathrm{a}}$ & 30 & 7.5 & 2.0 & $18^{\mathrm{a}}$ & 29 & 7.8 & 15 \\
\hline $4^{\mathrm{a}}$ & 29 & 6.8 & 18 & $19^{\mathrm{a}}$ & 27.5 & 7.3 & 20 \\
\hline $5^{\mathrm{a}}$ & 30 & 8.0 & 35 & $20^{\mathrm{a}}$ & 29 & 7.6 & 28 \\
\hline $6^{\mathrm{a}}$ & 28 & 7.5 & 34 & $21^{\mathrm{a}}$ & 30 & 7.2 & 27 \\
\hline $7^{\mathrm{a}}$ & 28 & 6.4 & 1.0 & $22^{\mathrm{a}}$ & 27 & 7.7 & 25 \\
\hline $8^{\mathrm{a}}$ & 28 & 6.5 & 7.0 & $23^{\mathrm{a}}$ & 31 & 7.5 & 29 \\
\hline $9^{\mathrm{a}}$ & 29 & 6.5 & 2.0 & $24^{\mathrm{a}}$ & 31 & 8.0 & 20 \\
\hline $10^{\mathrm{a}}$ & 30 & 6.5 & 2.5 & $25^{\mathrm{a}}$ & 32 & 7.0 & 24 \\
\hline $11^{\mathrm{a}}$ & 28 & 5.9 & 2.5 & $26^{\mathrm{a}}$ & 28 & 7.4 & 12 \\
\hline $12^{\mathrm{a}}$ & 29 & 7.0 & no detected & $27^{\mathrm{a}}$ & 27.5 & 7.5 & 36 \\
\hline $13^{\mathrm{a}}$ & 27 & 7.3 & 8.0 & $28^{\mathrm{a}}$ & 30 & 7.4 & 33 \\
\hline $14^{\mathrm{a}}$ & 31.5 & 8.0 & 9.0 & $29^{\mathrm{a}}$ & 31 & 7.5 & 25 \\
\hline $15^{\mathrm{a}}$ & 28 & 7.2 & 22 & $30^{\mathrm{a}}$ & 30 & 7.9 & 20 \\
\hline
\end{tabular}

\section{CONCLUSION}

Current major obstacles to human health in developing regions are well understood and a large component relates to unsafe water, poor sanitation and inappropriate hygiene. In this work the widespread presence of three pathogenic species genus of Aeromonas known to be involved in outbreaks of gastroenteritis, shows that despite our knowledge, pathogens continue to be a major issue for human health, and particularly so in developing regions. Monitoring pathogen distribution in public environments allied with educational programs that explain risk continues to be an important activity in developing regions.

\section{ACKNOWLEDGMENTS}

The authors thank the Fundação Cearense de Apoio ao Desenvolvimento Científico- FUNCAP, for financial support.

\section{REFERENCES}

1. Albert, M.J.; Ansaruzzaman, M.; Talukder, K.A.; Chopra, A.K.; Kuhn, I.; Rahman, M.; Rahman, M.; Faruque, A.S.; Islam, M.S.; Sack, R.B.; Mollby, R. (2000). Prevalence of enterotoxin genes in Aeromonas spp 
isolated from children with diarrhea, healthy controls, and the environment. J. Clin. Microbiol. 38, 3785-3790.

2. APHA. (1992). American Public Health Association. Standard Methods for the Examination of Water and Wastewater, 18th, APHAAWWAWPCF: Washington DC.

3. Chopra, A.K.; Houston, C.W. (1999). Enterotoxins in Aeromonasassociated gastroenteritis. Microb. Infect. 1, 1129-1137.

4. CLSI - Clinical and Laboratory Standards Institute. (2007). Performance standards for antimicrobial susceptibility testing; seventeenth informational supplement. CLSI M100-S17, Wayne, Pennsylvania.

5. Cunha, A.C.; Cunha, H.F.A.; Souza, J.A.; Nazaré, A.S.; Pantoja, S. (2005). Monitoring of superficial waters in estuary rivers in Amapá state under fecal pollution. Bol. Mus. Para. Emílio Goeldi, Ser. Ciências Naturais 1(1), 191-1995

6. Dumonter, S.; Krovacek, K.; Svenson, S.B.; Pasquale, V.; Baloda, S.B.; Figliuolo, G. (2000). Prevalence and diversity of Aeromonas and Vibrio spp in coastal waters of Southern Italy. Comp. Immunol. Microbiol. Infect. Dis. 23, 53-72.

7. Dupont, H.L.; Ericsson, E.D.; Reves, R.R.; Galindo, E.A. (1986). Antimicrobial therapy for travelers diarrhea. Rev. Infect. Dis. 8 (Supp12), S217-S222.

8. Evangelista-Barreto, N.S.; Vieira, R.H.S.F.; Carvalho, F.C.T.; Torres, R.C.O.; Sant'anna, E.; Rodrigues, D.P.; Reis, C.M.F. (2006). Aeromonas spp isolated from oysters (Crassostrea rhizophorea) from a natural oyster bed, Ceará, Brazil. Rev. Inst. Med. Trop. 48 (3), 129-133.

9. Fuzihara, T.O.; Pisani, B.; Simoes, M.; Brigido, B.M.; Silva, C.L.; Vannucci, L.; Arioshi, K. (2005). The occurrence of Aeromonas spp in drinking water. Rev. Inst. Adolfo Lutz 64 (1), 122-7.

10. Ghenghesh, K.S.; El-Ghodban,A.; Dkakni,R.; Abeid, S.; Altomi, A.; Tarhuni, A.; Marialigeti, K. (2001). Prevalence, Species Differentiation, Haemolytic Activity, and Antibiotic Susceptibility of Aeromonads in Untreated Well Water. Mem. Inst. Oswaldo Cruz 96 (2), 169-173.

11. Goñi-Urriza, M.; Capdepuy, M.; Arpin, C.; Raymond, N.; Caumette, P.; Quentin, C. (2000). Impact of an urban effluent on antibiotic resistance of riverine Enterobacteriaceae and Aeromonas spp. Appl. Environ. Microbiol. 66 (1), 125-132.

12. Hãnninen, M.-L.; Oivanen, P.; Hirvelä-Koski, V. (1997). Aeromonas species in fish, fish-eggs, shrimp and freshwater. Int. J. Food Microbiol. $34,17-26$

13. Hedges, R.W.; Smith, O.; Brazil, G. (1985). Resistance plasmids of aeromonads. J. Gen. Microbiol. 13, 2191-2195.

14. Hofer, E.; Reis, C.M.F.; Theophilo, G.N.D.; Cavalcanti, V.O.; Lima, N.V.; Henriques, M.F.C.M. (2006). Envolvimento de Aeromonas em surto de doença diarréica aguda em São Bento do Una, Pernambuco. Rev. Soc. Bras. Med. Trop. 39, 217-220.

15. Janda, J.M. (2001). Aeromonas and Plesiomonas. In: M. Susman, Molecular Medical Microbiology, Academic Press, San Diego, p.12371270.

16. Janda, J.M.; Abbott, S.L. (1998). Evolving concepts regarding the genus
Aeromonas: An expanding panorama of species, disease presentations, and unanswered questions. Clin. Infect. Dis. 27, 332-344.

17. Khadori, N; Fainstein, V. (1998). Aeromonas and Plesiomonas as etiological agents. Ann. Rev. Microbiol. 42, 395-419.

18. Klugman, K.P. (2003). The role of clonality in the global spread of fluoroquinolone-resistant bacteria. Clin. Infect. Dis. 36 (15), 783-785.

19. Knochel, S. (1990). Growth characteristics of motile Aeromonas spp isolated from different environments. Int. J. Food Microbiol. 10, 235244.

20. Krovacek, K.; Kui, H.; Sternberg, S.; Svenson, S.B. (1998). Aeromonas hydrophila septicemia in a grey seal (Halichoerus grypus) from the Baltic Sea: A case estudy. Comp. Immunol. Microbiol. Infect. Dis. 21, 43-49.

21. Maalej, S.; Manjoubi, A.; Elazri, C.; Dukan, S. (2003). Simultaneous effects of environmental factors on motile Aeromonas dynamics in an urban effluent and in the natural seawater. Water Res. 37, 2865-2874.

22. Marcel, K.A.; Antoinette, A.A.; Mireille, D. (2002). Isolation and characterization of Aeromonas species from an eutrophic tropical estuary. Mar. Pollut. Bull. 44, 1341-1344.

23. Martin-Carnahan, E.; Joseph, W.S. (2005). Aeromonas. In DJ Brenner, NR Krieg, JT Staley, GM Garrity (eds). Bergey's Manual of Systematic Bacteriology, 2nd Ed., v.2, Springer-Verlag, New York, p. 556-578.

24. Minnaganti, V.R.; Patel, P.J.; Lancu, D.; Schoch, P.E.; Cunha, B.A. (2000). Necrotizing fasciitis caused by Aeromonas hydrophila. Heart Lung. 29, 306-308.

25. Moraes, D.S.L.; Jordão, B.Q.O. (2002). Degradação de recursos hídricos e seus efeitos sobre a saúde humana. Rev. Saúde Pública, 36 (3), 370374.

26. Moyer, N.P. (1987). Clinical significance of Aeromonas species isolated from patients with diarrhea. J. Clin. Microbiol. 25, 2044-2048.

27. Palumbo, S.A.; Morgan, D.R.; Buchanan, N.L. (1985). Influence of temperature, $\mathrm{NaCl} \mathrm{e} \mathrm{pH}$ on the growth of Aeromonas hydrophila. J. Food Sci. 50, 1417-1421.

28. Palumbo, S.; Abeyta, C.; Stelma, G.; Wesley, I.W.; Wei, C.; Koberger, J.; Franklin, S.K.; Tucker, L.S.; Murano, E.A. (1992). Aeromonas, Arcobacter and Plesiomonas. Cap.30, p.283-290. In: "Compendium of Methods for the Microbiological Examination of Foods". 3 ed. Washington: American Publis Health Association (APHA), 1912p.

29. Palu, A.P.; Gomes, L.M.; Miguel, M.A.L.; Balassiano, I.T.; Querioz, M.L.P.; Freitas-Almeida, A.C. (2006). Antimicrobial resistance in food and clinical Aeromonas isolates. Food Microbiol. 23, 504-509.

30. Pereira, C.S.; Amorim, S.D.; Santos, A.F.M.; Reis, C.M.F.; Theophilo, G.N.D.; Rodrigues, D.P. (2008). Caracterização de Aeromonas spp isoladas de neonatos hospitalizados na cidade do Rio de Janeiro. Rev. Soc. Bras. Med. Trop. 41, 179-182.

31. Pereira, C.S.; Possas, C.A.; Viana, C.M.; Rodrigues, D.P. (2004). Aeromonas spp e Plesiomonas shigelloides isoladas a partir de mexilhões in natura e pré-cozidos no Rio de Janeiro/RJ. Cienc. Tecnol. Aliment. 24, 562-566. 
32. Rall, V.L.M.; Iaria, S.T.; Heidtmann, S.; Pimenta, F.C.; Gamba, R.C.; Pedroso, D.M.M. (1998). Aeromonas species isolated from pintado fish (Pseudoplatystoma sp.): virulence factors and drug susceptibility. Rev. Microbiol. 29, 222-227.

33. Rhodes, G.; Huys, G.; Swings, P. M.; Mcgann, P.; Hiney, M.; Smith, P.; Pickup, R.W. (2000). Distribution of oxitetracycline resistance plasmids between aeromonads in hospital and aquaculture environments: implication of $\mathrm{Tn} 1721$ in dissemination of the tetracycline resistance determinant Tet A. Appl. Environ. Microbiol. 66, 3883-3890.

34. Rodrigues, D.P.; Ribeiro, R.V. (2004). Aeromonas. In: Vieira, RHSF (coord.). Microbiologia, higiene e qualidade do pescado: teoria e prática. Varela: São Paulo, p.151-174.

35. Sautour, M.; Mary, P.; Chihib, N.E.; Hornez, J.P. (2003). The effects of temperature, water activity and $\mathrm{pH}$ on the growth of Aeromonas hydrophila and subsequent survival in microcosm water. J. Appl. Microbiol. 95, 807-813.

36. Schmidt, A.S.; Bruun, M.S.; Dalsgaard, I.; Larsen, J.L. (2001). Incidence, distribution, and spread of tetracycline resistance determinants and integron-associated antibiotic resistance genes among motile aeromonads from a fish farming environment. Appl. Environ. Microbiol. 67 (12), 5675-5692.

37. Torres, D.P.C. (2004). Aspectos do tratamento biológico de esgotos domésticos. Rev. Cient. IMAPES, 68-70.

38. Wegener, H.C.; Moller, N.F. (2000). Reducing the use of antimicrobial agents in animals and man. J. Med. Microbiol. 49, 111-113. 